\title{
Literature Reads the City: Italian Writers Facing the Changes of Milan during the Italian Economic Boom
}

\author{
By Dino Gavinelli ${ }^{*} \&$ Giorgia Schiappadori ${ }^{ \pm}$
}

In the second post-war period in Milan different kinds of urban, industrial and productive regenerations were started. These innovations were developed in the following decades and laid the basis for a new dynamism, which is still a key characteristic of 'the most European city in Italy'. The urban landscape has progressively been reshaped thanks to innovative territorial policies, and the inhabitants of Milan have seen deep changes in their city. These spatial dynamics have inspired the literary production of some Italian writers, in particular during the period between the Sixties and the Seventies, an extremely prolific period for cultural life in Milan. Prose writers as Luciano Bianciardi and poets as Vittorio Sereni and Alda Merini witnessed the transformations of those years, the industrial growth, the strong economic development and the new Milanese cultural scene. The purpose of this work is to highlight how these literary creations can be a useful source, not only because of their undisputed artistic value, but also because they recreate social, historical, geographical, architectural and urban events of those days. In addition, they can help us to understand the urban context and the Milanese landscape during the Italian economic boom.

Keywords: Milan, Literature, Economics, Geography, Regeneration, Vittorio Sereni, Alda Merini, Luciano Bianciardi.

\section{Introduction}

Since the end of 1950s and up to the first decade of 1960s, Milan had a huge development of many productive sectors, a period known as "economic miracle". After this time, which had a big influence on social and economic Milanese life, an intense deindustrialization occurred, since the 1960's and up to the 1980's. It led to a development of: the tertiary sector; service activities; enterprises and, in particular, of the fourth sector. Economic globalization, the spread of information and the new society of culture have started, since 1990's, various decomposition and re-composition processes inside the city. These ones reinforced the interdependences of networks and flows, calling into question political and settlement balances of all these spaces inherited by history. Therefore, Milan has known in the last decades the industrial decline and its restructuring, in a progressive productive transition towards service and fourth sectors, while the neo-liberalism and the globalization were taking hold (Bonomi and Abruzzese 2004, Molinari and Pietta 2009).

Urban landscape has suffered from these causes and has been involved in difficult architecture disposal, abandon and restoration processes of urban structures and working spaces. Furthermore, the new spaces for leisure and

\footnotetext{
*Professor, University of Milan, Italy.

${ }^{ \pm}$Digital Consultant at $3{ }^{\text {rd }}$ Place - Milan, Italy.
} 
personal time have given their contribution to change the new Milanese urban landscape. Milan has become a complex and problematic city during the years: the landscape is divided between the inherited legacy of the past and the new changes of the production cycles. This evolution gives hope, concern, foments a cultural debate, encourage geographic analysis and gives sparks for a large literary production (Anceschi 1952, Ferretto 1968, Collot 2005). Yet, we could wonder how it happened? How a city has passed from the ruins of the Second World War to be the Italian metropolis, which also hosted Expo 2015, demonstrating to be the "most European city" of this country?

The complexity of these questions is so powerful that needs many looks and competences to be answered. The "Milanese urban matter" crosses many fields of knowledge and finds some representations not only in geographers' works, but also in the lyric poem and poetry of many Milanese narrators (Fortini 1977, Rosa 2004). Great writers such as Vittorio Sereni, Alda Merini and Luciano Bianciardi, chosen among the wide range of writers we could mention, were able to describe in their amazing works, the spatial dimension of Milan. They were sensitive about understanding and describing Milanese transformations of their years.

In this essay, we are analysing the feelings and the sensibility of the three authors to let the readers know how poetic and narrative texts can give useful information to understand the social and territorial transformations that have occurred in Milan in the last decades and we are collecting the most significant geographers' lucubration about this theme. Literary productions about the history of the Lombard capital city will be narrated and compared in this essay to promote a geo-literary reflection about the past and the present of the city of Milan.

\section{Territorial "Decomposition" and "Recomposition": Between Geography and Literature}

The reconsideration of the organisation of the city has nurtured a wide geographical debate about the future of the metropolitan area of Milan. The Lombard capital and its urban region are a heterogeneous, social, economic, anthropologic, linguistic, cultural, symbolic, conflictual scenario, a complex product projected by humanity (Gonzales 2007, Bolocan Goldstein 2009, Gavinelli and Morazzoni 2012).

Changes and processes in action put in question the concepts inherited by the past of "spatiality" and "scales": both the geometric-areal ones (formalized during the modern era and thanks to the rationalist approach), and those humanistic and postmodernist ones (of the last decades) (Gavinelli 2010).

Globalization also generated a reticular "spatiality", in which traditional space-temporal territorialisation forms (country, regions, not urbanised areas, cities, urban networks and metropolis, with their borders and floods of people and goods) and their material and immaterial manifestations (places, landscapes, cultures, technologies, resources, perceived and lived spaces, existential values, representations, and narrations) decomposed and composed again on new basis, in a delicate and dynamic balance of permanence and transformation, reality and 
narrations, interaction between local and global (Castells 1984). In all these cases, Milan with its possible temporal, spatial declinations, its concrete and symbolic values (urban network, metropolitan area, real and described landscape, social relations and working places, leisure and touristic spaces), its transformations, results a paradigmatic and crucial joint in the decomposition and composition processes of the wider territory which surrounds the city itself.

It often happens that the new polarisation, events, public spaces, suburbs, challenges of the quality of urban life, giving a temporary limit, impose a deadline, a purpose for future. Changes must be accelerated and increased, and they are described by geographer sometimes, and felt by authors in other cases. All these transformations, the appearance of hybrid forms to use urban spaces, the innovative mixture among residential, productive and leisure areas, define outlines spaces, which can be multifunctional, "porous", "fluid and liquid" places, which attract geographers' analysis and writers' narrations (Bauman 2006, Bonomi and Abruzzese 2004, Champion and Hugo 2004, Perulli 2007). That said, the result is a marked sensibility about: changes; spatial and temporal discontinuity; new styles and models of urban life; the conservation of material and immaterial city property; the architectonic quality; the mix of aesthetic dimension and of the morphological and functional one (Scaramellini 1993, Scaramellini 2011).

\section{Milan and Its Last Decades' Changes}

A wide public discussion has been fomented by the new city spatial organization. In this geographical and extra-disciplinary debate about the future of the metropolis as an extended human product, Milan and its urban region reveal themselves as a heterogeneous territorial, social, economic, anthropologic, linguistic, cultural, symbolic scenery. It is difficult to understand the real boundary lines, always moving, with infinite forms and typologies variations (Gonzales 2007, Bolocan Goldstein 2009).

In this situation, to better understand how to move inside the Milanese complex processes of spatial transformation, the first path to follow could be the one offered by the significant changes of the last thirty years in the requalified industrial areas. This process emphasises continuity with the "Fordist past" on one side, through the redefinition of the enterprises localization, and the importance of the new restoration urban policy on the other side. Restoring, recycling, reusing, regenerating, are the new gestures realized also because of the lack of an urban overall strategy, which should be codified in a coherent, urbanistic and unitary urban-planning (Bolocan Bonfantini 2007).

It has often happened that the industrial patrimony has been enhanced not only as a group of values to be maintained, yet, also as a cultural heritage to be used to reach the economic and physical city rebirth, in particular by single politic or economic parties. The structural decline of the industrial sector has left an impressive and austere inheritance, and the urban environment suffers from these infrastructures that divide with visible boundaries residential parts, factories and urban forestry. 
These industrial abandoned areas could be considered as "functional islands" with rigid boundaries, physical separations as walls or gates, squares and track lines, which have favoured industrial time and space for a long period. Given this, we can affirm that this kind of division has also favoured capitalism needs above society needs, excluding leisure and outdoor activities from the employees' daily life.

Many elements coming from this Fordist era are still visible in Milan, and they have already been narrated by many geographers and writers (Dalmasso, 1972, Corna Pellegrini 1985). These places are "vacant urban spaces", untouched by the dynamic and the daily rhythm of the city, they represent the productive abandonment, the "architectonical waste", ruins created by humans.

Restoring and recovering these places means that we could have a new asset to count on, and it has happened in the last decades, in particular because of private interests. In many cases, private help has been more useful than state administration in this urban transition, to trigger structural local development processes and to start a new way of tourist enhancement (Amendola 2003, Mastropietro 2013).

A second path to move among the complex processes of Milanese transformation is provided by political analysis, which let us understand how Milan wants to provide for the economic development and also for a growth of cultural sector, tourism, leisure and creativity. New projects among public and private parties, local and global factories, have led to a reshape of the urban morphology in many parts of the city. The most enhanced sectors that have converted many marginal and declassed areas in rising spaces, have surely been: fashion, design, culture, leisure, education, finance, new technologies, tourism. Social substitution, building requali-fication and a new "morphologic" design validate gentrification, urban branding and marketing, as for the historic renovated neighbourhoods of "Porta Genova-Savona-Tortona", "Isola", "GaribaldiRepubblica", "Ticinese", "Rogoredo", "Bovisa", "Bicocca", "Via Ventura" and "Lambretto". In Milan, this process has not been planned; it has spontaneously grown, as a result of personal, aesthetic, individual choices. Institutions and development companies intervene subsequently, attracted by money and power. This growing space complexity, this new events and actors, make difficult to evaluate the real value given to culture, creativity and arts, not only in Milan, but in every regenerated city (Morazzoni De Ponti 2011).

These described paths interlace themselves in many cases, increasing each other and becoming a fundamental component of theoretical projects, in progress or already done, in the urban or suburban areas (Bolocan Goldstein 2009). These projects have been started not only to recover, recycle and re-functionalizing abandoned industrial areas, but also to direct the image and the narration of a renovate city in the productive and residential networks. Realizing these activities also means that some addresses and common evolutionary lines can be identified. These "plans" have been done in relation to the big strategies to revamp some areas in a sustainable way.

Furthermore, sometimes these projects don't allow discovering completely all the procedures, the involved sectors, the delicate financial and administrative 
balance, the private and public role, the "third sector" moves and the involvement of voluntary work in responding to territorial needs. Moreover, is not so easy to understand the link between profitability and social components: private enterprises, in the majority of cases, not only give financial support, but also cultural and social help, giving a precious "know how" and their technical, financial, organizational experience.

Enterprises hand down their knowledge from production to social level, creating positive synergies between these worlds that too often have been separated, in particular in the Milanese area. Hence, the attempt to describe, in this essay, the novelty and the discontinuous elements of cultural renovation in public and private spaces that have been put in place since the end of the twentieth century and the beginning of the twenty first century can not be exhaustive. We should study them again in the coming years. Physical, symbolic, permanent or temporary changes of the last decades have become the visible part of a renovated and wider planning, which takes into account the opportunities of global markets, the needs to have a new urban image and the city's economy.

Milan has to overcome this dualism of "enterprise-city", exploiting every kind of events. Therefore, the city has started significant transformations in its urban experience, through: the creation of new skyscrapers and immense shopping malls; the demolition of parts of traditional buildings; the creation of international and national spaces and symbols; the repositioning of the city inside the global network.

\section{Vittorio Sereni}

Vittorio Sereni was born in 1913 and died in 1983. During his life he has been a teacher in high school before the First World War, and then was hired by Pirelli, one of the greatest Milanese enterprises. Afterwards, he became executive in Arnaldo Mondadori publishing house, since the last years of 1950's. He was the poet of the "pain of living", writer of the human condition; he has always been menaced by the sense of emptiness. Narrator able to catch "the absurd" and write it down through verses and lapidary words: "seeing that nothing, nothing has really changed anything" (a); "the existence repetition"; "the colour of emptiness"; "nothing, nobody, in no other place" (b) (Sereni 2014a, b).

Following the hermetical guide of Eugenio Montale, Sereni redeemed the human condition of emptiness only for some instants, because reality is characterized by an eternal return of situations, it only leaves few moments of lucidity and fullness, or, more often, some moments of sensitiveness that allow us to escape from repetition and monotony. Sereni became a sort of guardian of these little moments. He has not written so much, just because he wanted to catch fragments, inspirations, he narrated the fate, the magic of some breathless instants. The writer often spoke about a world characterized by "the absurd", finding particular situations only sometimes, only in some places (Collot 2005).

In this way, his most wise and important poetry collection called "Human instruments" (1965) narrates a veteran's history (the story of his life) in Milan, 
after the Second World War. This city, capital of the technological civilization of that period, appears as the epicentre of the larger Italian transition from a premodern condition towards the reconstruction, the industrial development, the third sector and the fast urbanisation. All these transformations have changed the rural landscape in a more complex panorama, with its urban and productive areas between the " $50 \mathrm{~s}$ and the ' $70 \mathrm{~s}$.

His total commitment and his direct confrontation with reality contradictions, constituted the main structure of his deep poems, which show the neo-capitalist industry and society after the Second World War, and lead us to meditate on the past. He denounced the end of hopes and of values; he criticized the agreements done after war, which frustrated the resistance against Nazism and Fascism. With this in mind, Sereni described another important writer, Umberto Saba (18961981). Saba was enthusiast about Italian politics and once he wandered through Milanese cafés saying “Damn, Damn!" against those ungrateful Italians who, in a delicate moment for their country, had voted for right parties, behaving as a woman who "unaware or not, fatally injured us", as Sereni wrote in his masterpiece. And again, his work "Human instruments" describes Milan in its daily life of that time, in its antithetical landscapes, with its factories working at a spanking pace and its places of social exclusion, of boredom.

Many of his poems record the fast and tumultuous urban Milanese transformations, as in a travel diary, he wrote about his tram rides throughout the city (The sleep), describing the congested main roads (Corso Lodi) or the secluded, narrow roads. He lived in one of these streets, Via Scarlatti, near the Central station, the main entrance to the city for thousands of people who have come to Milan seeking fortune in the economic Italian capital city. Via Scarlatti in his poems is a sort of pacific oasis, among the noise and the congestion of the streets around the station. Here, the poet narrated about his daily life and his peaceful place, as he wrote in "Via Scarlatti" poem. These same feelings were felt by Luciano Bianciardi and Alda Merini too: Milan has got hidden places which still today become refuges for its inhabitants.

Thanks to these verses, he showed the daily life dynamism and its multifaceted aspects. Interest is immediate for anything changing and for the immediacy of time, for the unloved society. Although, analysing his poetry nothing really has a sense and the most evident colour is "emptiness", world has always been changing and Sereni was interested in its new panorama, its new individuals, new things and passions on the earth's surface that mislead people with their presence. On this double literary register is designed "Another Birthday", which close his last poetic collection, "Variable Star" (1981). Vittorio Sereni in this poem is in a pub, in Milan suburbs, looking at the San Siro stadium, silent and illuminated by the sun, witness of a finished championship. Another football season is over, and people are impatiently waiting for another season to come, during next autumn. The large square is empty as a metaphor of his waiting for a new energy, for new illusions helping him to face the true of life, challenges that come toward him as impetuous waves. "Another birthday" is inspired by times, situations and spaces taken from reality (as the football agenda, the pub, San 
Siro neighbourhood with its square and stadium) but also by meditation, the sense of life and its value.

We can foresee that Sereni has gone beyond the certainty of his strong position about inhabits and values of his time, searching for the real humanity over the economic interest, far from situations, things, spaces, in particular far from the empty ones (Renard 1991).

\section{Luciano Bianciardi}

Luciano Bianciardi was born on $14^{\text {th }}$ of December 1922 in Grosseto and died in Milan on the $14^{\text {th }}$ of November 1971. He was not just a writer, but also an essayist, a journalist, a translator, a passionate narrator of Italian life of his period. Although he belonged to the Milanese cultural élite of " $50 \mathrm{~s}$, he has always taken position against the new "rules of the game" introduced by the "economic boom", which changed not only the capital urban landscape, but also the Milanese social landscape.

The land transformation and the socio-cultural changes are narrated in his books, and tells about how television has gradually substituted radio; about dialects mixing while people was resettling from a region to another; about southern centres emptying while northern centres were being invaded by newcomers.

The historical geographical references in his texts are extended to the labour culture, also called "popular culture" or "subculture". The idea is that they are extended to a sort of "subordinated" and "subservient" proletariat. Yet, the reader can also find pages in which some forms of resistance to a "mass culture" are studied; these forms are composed by a set of phenomena created by the "boom" and indicted by left-wing intellectual, accused of trying to replace proletarian cultural roots with consumerism.

Bianciardi spoke out against the above society that belonged to the "economic miracle", denouncing injustices in a book collection, which mix fantasy with nonfiction. Arrived at the publishing house Feltrinelli in Milan, in 1955, he started accusing the great contradictions of the "economic boom". He published two autobiographical inspired works: the first one was by Feltrinelli, entitled "The cultural work" (1957), in which he ironically narrates the education of a provincial intellectual during the "50s; the second by Bompiani, entitled "The integration" (1960), in which a man of culture is engulfed by a big city, by an industrialized world that upsets and overwhelms him.

These two autobiographies culminate in his masterpiece, "It's a hard life" (1962). In this book he expresses all his anger and anguish towards the world of the "economic miracle" which has enriched and devastated Milanese society and territory. This novel narrates about people who live in inhuman and degrading conditions, in the urban alienation; this state leads to live in a continuous nausea caused by pollution, wasting money and food, searching for a status quo given by fashion and richness. Citizens approved by society are considered negatively, as if 
they were identical puppets, only interested in money and not able to see the negative effects of this society.

Today, these themes are current topics and help us to better understand the political, economic and socio-cultural decadence of our days, through an open-eye approach. Society easy illusions, the cultural and socio-territorial problems described are given by all these changes that made the "economic miracle" possible. All these items play a fundamental role and erase the remains of rural and agricultural values. The feeling of being squeezed by the system and its fundamental tendency to anarchy were the main causes of his dismissal from Feltrinelli, prelude of a more and more descending literary production and of his increasing alcoholism that will bring him to his self-destruction.

Also in "It's a hard life" the protagonist let his anarchic side fall asleep, as if the city were a soporific that anesthetized rebellion instincts, that makes people fall into line. The observation of the described urban spaces is a possible way to understand protagonist's feelings: his growing degree of estrangement is directly proportional to his presence in the city, in the historical city centre before and in the grey periphery after. The described urban geography of his novel reflects the characters' interiority. Buildings, bars, roads and other city's elements disappear through the fog, which renders everything indistinct, as the protagonist's purposes disappear along the way. Citizens live as they were in a sort of "collective trance", part of an indistinct mass, a shapeless flood of humans.

Only in certain places, like at the "Osteria" in Via Lanzone, in Brera neighbourhood, he manages to discover again the beauty of simple things, kept alive by few citizens. Outside Brera, the city is hostile, composed by soulless neighbourhood in which there is no sympathy. Even among the workmen at the Central Station he cannot find friends or fellows, because everyone fights against the others, everyone is selfish. The flattening has become apathy, habit and frustration.

Milan becomes an emblem of indifference. It's the city of the heightened consumerism, of people losing identities, becoming only consumers. The modern metropolis opposes to the disappearing rural reality: fields becoming offices, places in which spiritual dehydration goes up to the highest levels. People's interior geography reflects outside, the foggy weather. Fog seems to suffocate everyone and everything, losing ancient values, tradition and culture, the past human and artistic heritage will not come back anymore, leaving us among glass buildings which still today represent profit and unsustainable consumerism (Rosa 2004, Bernini et al. 2016).

\section{Alda Merini}

Another famous writer of the Milanese contemporary life is Alda Merini. Unlike Bianciardi, she was born in Milan, the $21^{\text {st }}$ of March 1931, and she spent the main part of her life in this city, where she died on the first of November 2009. She is known in particular as a poetess; she had many troubles due to her schizophrenia and misadventures. Her frequent hospitalization, her husband in 
Taranto, some travels is the only reasons why she has left the city sometimes, physically or mentally.

Milan is often described as a woman able to feed many people from the whole world, appearing a cosmopolitan centre, but also an insensitive and cold city. Here and there, "Bianciardi's Milan" survives, among Brera and the "Navigli", and Alda proposed these places again in a feminine perspective, some years later.

It's impossible to compose an Alda's complete biography, her poetic production is so broad that only the part published by "Pulcinoelefante" edition is composed by more than 1100 titles. Some of her most famous works are: "The presence of Orfeus" (1953) "; "Roman wedding" (1955) ${ }^{2}$; "Afraid of God" (1955) ${ }^{3}$; "You are Peter" (1961) ${ }^{4}$; "Destined to die. Old and new poems" (1980). ${ }^{5}$

Many of her poems were composed at home or in her neighbourhood as at "Caffè Chimera", attended also by other famous writers. The poetess has lived since 1986 until 2009 in "Ripa di Porta Ticinese" 47, accumulating inside her house works, thoughts, poems written on the wall with her lipstick, paintings, photos, heaters and fans. Alda completed her life hosting cats, friends and a homeless nicknamed Titan (official website: www.aldamerini.it).

Her home became a meeting place and a privileged place for her poems; other narrated places are these ones around the "Navigli": Vico dei Lavandai, Saint Christopher Church, the Darsena, in a love-hate relationship for a city that she felt deeply inside her, but that she could not recognize anymore because of its fast mutations. The poetess was confined in a mental hospital, the "Paolo Pini", among the indifference of many citizens. When she came out, she gave us a new strong, rational and lucid vision of life and of her beloved places.

Relationship between narrative and the city has often been neglected, yet novels by Sereni, Bianciardi and Merini are always useful to talk about a metropolis still able to attach with its history, its neighbourhoods, its real soul. These authors described a city composed by taverns, artisans, workmen, by an industrious daily life, by a society and a landscape which progressively change, by great men and by everyday people. Alda Merini narrates about a city changing and growing: from the war period, towards modernity, from poverty to luxury, from generosity to profit, losing past values and symbols. Milan is the example of this change, which comes until nowadays. Poems and novels become history books, which allow us to reconstruct the most particular aspects of the past and current urban landscape (Raboni 1976, Ramat 1976, Rosa 2004).

\section{Conclusions}

In this article we have gathered references by three main Italian authors (Vittorio Sereni, Luciano Bianciardi, Alda Merini) considered to be significant in

\footnotetext{
${ }^{1}$ Merini A (1953) The presence of Orfeus, Milano, Ed. Schwarz.

${ }^{2}$ Merini A (1955) Roman wedding, Milano, Ed. Schwarz.

${ }^{3}$ Merini A (1955) Afraid of God, Milano, All'insegna del Pesce d'Oro.

${ }^{4}$ Merini A (1961) You are Peter, Milano, Ed. Lunario.

${ }^{5}$ Merini A (1980) Destined to die. Old and new poems, Poggibonsi, Lalli.
} 
order to rebuild the rapid and profound changes happened in the socio-economic fabric and in the environment of Milan since the second post-war period (Gavinelli 2012, Gaccione 2013, Bigatti and Lupo 2014). Their literary works let us perceive not only the most macroscopic aspects of a city that has intimately and radically redesigned its urban landscape during the last decades, driven by reconstruction, economic boom, modernisation, technological development and globalization, but also to carry out a more intimate and detailed geographical narration.

In this narration we are able to observe the urban districts daily life, the material and immaterial pressure between the past and the present of the city, the doubts about Milan future, which, starting from being a regional and national centre, opens itself to an international urban competition (Bernini et al. 2016).

Reading the works of Sereni, Bianciardi and Merini allows us to detect their deep attachment to an urban territory, which is perceived in its most intimate evolution, in its deepest cultural fervour. Their poetry and prose productions demonstrate how the geographer, in his effort to rebuild the spatial reality and its evolutions, could draw on literary works in order to better seize the complexity and the development of territorial processes. (Tissier 1992, Casari and Gavinelli 2007, Bédard and Lahaie 2008).

\section{Acknowledgements}

This article is the result of shared reflections between the authors. More specifically, the introduction and the chapters about Vittorio Sereni, Luciano Bianciardi and Alda Merini are written by Giorgia Schiappadori, while the other paragraphs are written by Professor Dino Gavinelli.

\section{References}

Anceschi L (1952) Linea Lombarda. Sei Poeti. [Lombard Line. Six Poets]. Varese: Edizioni Magenta.

Amendola G (2003) A Postmodern City. Magics and Fears of the Contemporary Metropolis. Bari-Roma: Laterza.

Bauman Z (2006) Modernità Liquida [Liquid Modernity], 272. Roma-Bari : Laterza.

Bédard M, Lahaie C (2008) Géographie et littérature: entre le topos et la chôra. [Geography and literature: between the topos and the village]. Cahiers de Géographie du Québec 52(147): 391-397.

Bernini F, Cucchi M, De Angelis M, Lamarque V, Lerro R, Majorino G, Neri G, Pellegatta A, Recalcati C, Rossi T, Santagostini M, Valduga P (2016). Quartieri di poesia. Milano in Una Galleria D'immagini e di Voci [Poetry Neighbourhoods, Milan in Images and Voices Gallery]. Milano: Meravigli Edizioni.

Bianciardi L (1962) It's a Hard Life. Milano: Feltrinelli.

Bianciardi L (1957) The Cultural Work. Milano: Feltrinelli.

Bianciardi L (1960) The Integration. Milano: Feltrinelli.

Bigatti G, Lupo G (2014) Fabbrica di Carta. I Libri che Raccontano l'Italia Industriale [Paper Factory. Books narrating the Industrial Italy] 348. Bari-Roma: Laterza. 
Bolocan Goldstein M (2009) Geografie Milanesi [Milanese Geographies], 238. Santarcangelo di Romagna: Maggioli Editore, «coll. Politecnica ».

Bonomi A, Abruzzese A (2004) La Città Infinita. [The neverending city], 319. Milano: Bruno Mondadori.

Casari M, Gavinelli D (2007) La Letteratura Contemporanea Nella Didattica Della Geografia e Della Storia. [Contemporary Literature in the Teaching Methodology of Geography and History], 20: 167. Ricerca e Didattica della Geografia Milano. Milano: CUEM.

Castells M (1984) European cities, the informational society and the global economy. New Left Review I(204): 18-32.

Champion T, Hugo G (2004) New Forms of Urbanisation. Beyond the Urban-Rural Dichotomy, 420. Aldershot: Ashgate.

Collot M (2005) Paysage et Poésie du Romantisme à nos Jours. [Landscape and Poetry of Romanticism nowadays], 446. Paris: Editions José Corti.

Corna Pellegrini G (1985) Milano. Le ragioni di una visita. [Milan. The reasons why visit it]. Milano, coll. «Guide d'Italia», 691. Milano: Touring Club Italiano.

Dalmasso E (1972) Milan, Capitale Économique de l' Italie. [Milan, the Italian Economic Capital], 583. Gap: Editions Ophrys.

Ferretto GC (1968) La Letteratura del Rifiuto e Altri Scritti. [The Refusal Literature and Other Works], 484. Milano: Mursia.

Fortini F (1977) I Poeti del Novecento. [The Twentieth Century Poets], 243. Bari: Laterza.

Gaccione A (2013) Milano Città Narrata. [Milan the Narrated City], 160. Milano: Editore Meravigli.

Gavinelli D (2010). Gli spazi della finzione letteraria e della geografia. [The spaces of literary fiction and of geography]. In Treccani.it L'Enciclopedia Italiana. http://www. treccani.it/scuola/tesine/letteratura_e_geografia/gavinelli.html.

Gavinelli D, Morazzoni M (2012) La Lombardia Occidentale, Laboratorio di Scomposizione e Ricomposizione Territoriale: Da Ambiente Naturale a Spazio Megalopolitano. [Western Lombardy, Territorial Breakdown and Recomposition Laboratory: From Habitat to Megalopolitan Space], 2: 200. Milano-Udine: Mimesis, coll. «Kosmos».

Gavinelli D (2012) Scomposizioni e ricomposizioni territoriali: letture geografiche su Milano e la sua regione urbana. [Territorial breakdown and recomposition: geographic readings about Milan and its urban region.], 11-36. In D Gavinelli, M Morazzoni (eds) La Lombardia occidentale, laboratorio di scomposizione $e$ ricomposizione territoriale: da ambiente naturale a spazio megalopolitano. MilanoUdine: Mimesis, coll. «Kosmos».

Gonzales X (2007) Geographic and Didactic Education of Geography. Valencia: Espacio geográfico y educación para la ciudadanía, In Revista Didáctica Geográfica, 9: 11-31.

Mastropietro E (2013) Europe Projects the City. Milano-Udine: Mimesis, coll. «Kosmos».

Molinari P, Pietta A (2009) Competitività e sostenibilità in Lombardia. Una valutazione delle dinamiche e delle politiche in atto nelle province. [Competitiveness and sustainability in Lombardy. An evaluation of dynamics and policies in the provinces]. Geotema 11(31-32): 49-59.

Morazzoni M, De Ponti P (2011) Milano Leisure. Realtà, Immagine, Immaginario. [Reality, Images, Imaginary], 141 p. Legnano: Piccoli Giganti Edizioni, coll. «Parallelo Zero. Geografie Metropolitane».

Perulli P (2007) La Città. La Società Europea Nello Spazio Globale [The City. The European Society in the Global Space], 181. Milano: Bruno Mondadori, coll. «Campus». 
Raboni G (1976) Poesia Degli Anni Sessanta [The Sixties Poetry], 269. Roma: Editori Riuniti.

Ramat S (1976) Storia Della Poesia Italiana del Novecento [History of Italian Twentieth Century Poetry], 701. Milano: Mursia, coll. «Civiltà letteraria del 900. Sezione italiana».

Renard P (1991) D'un seul lieu, de nul lieu [From one place to no place], 265-274. In V Sereni (ed) Les Instruments humains. Lagrasse : Verdier, coll. «Terra d'altri».

Rosa G (2004). Identità di una metropoli: la letteratura della Milano moderna. [Metropolis identity: modern Milan literature.], Nino Aragno Editore, Torino collezione Zapping. Available at: http://www.liberliber.it/mediateca/libri/r/rosa /identita_di_una_metropo li/pdf/identi_p.pdf.

Scaramellini G (1993) Funzioni Centrali, Funzioni Metropolitane, Reti Urbane. Saggi e Ricerche Sulle Nuove Forme di Organizzazione Del Territorio [Central functions, Metropolitan Functions, Urban networks. Essays and Studies about the New Territorial Organisational Ways], 380. Milano: FrancoAngeli.

Scaramellini M. (2011) Milano. Lavori in corso. La metropoli lombarda dal "miracolo" economico all'attuale crisi mondiale. [Milan. Work in progress. The Lombard metropolis from the economic "miracle" to the present global crisis], 13-39. In Muscarà C (eds) Tante Italie una Italia. Dinamiche territoriali e identitarie. Vol. IV: Nordovest: da Triangolo a Megalopoli. Milano: FrancoAngeli.

Sereni V (2014a) Un Altro Compleanno [Another Birthday], 1-369. Esposito E. (a cura di). Milano: Ledizioni LediPublishing.

Sereni V (2014b) Gli Strumenti Umani. [Human Tools], 100. Torino: Einaudi, 1965.

Tissier JL (1992) Géographie et littérature. [Geography and literature], 235-255. In A Bailly, R Ferras, D Pumain, (eds) Encyclopédie de Géographie. Paris: Economica. 